\title{
Effectiveness Of Video Assisted Teaching Programme (V.A.T.P.) On Selected Respiratory Problems In Knowledge And Respiratory Status Among Workers In Selected Spinning Mill
}

*Mrs.Kalpana Ramesh

\begin{abstract}
:
Objectives: To assess the effectiveness of V.A.T.P. on selected respiratory problems. Method: Pre experimental study with a evaluative approach was undertaken on 40 workers. Result: Prior to implementation of V.A.T.P.the workers had inadequate knowledge ,moderate level of respiratory symptoms and decreased peak expiratory flow rate, whereas after implementation of teaching programme the workers knowledge and peak expiratory flow rate was improved and level of respiratory symptoms were decreased. Conclusion: The knowledge and respiratory status of the workers regarding selected respiratory problems significantly improved with the difference of mean percentage revealing effectiveness of V.A.T.P.
\end{abstract}

Key words: Video Assisted Teaching Programme, Respiratory Problems, Spinning Mill.

\section{INTRODUCTION}

Every occupation is associated with one or other ill effects on health . One such occupational group are the cotton textile workers. Indian Textile industry is one of the leading textile industries in the world and also contributes nearly $14 \%$ of the total industrial production of the country. India textile industry is also the largest in the country in terms of employment generation ,currently generates employment to more than 35 million people .It's also estimated that, the industry will generate 12 million new jobs by the year 2010 - India, Business directory (2010)

Occupational health is the science of designing, implementing and evaluating comprehensive health and safety programs that maintain and enhance employee health, improve safety and increase productivity in the work place.

Cotton textile workers are susceptible to various respiratory morbid conditions, by virtue of work place and working conditions and at risk of suffering from various chronic respiratory illnesses like byssinosis, chronic bronchitis due to exposure to the cotton dust in the worksites.

\section{OBJECTIVES OF THE STUDY:}

To assess the pretest and posttest level of knowledge on selected respiratory problems among workers in selected spinningmill.

To assess the pretest and posttest level of respiratory status among workers in selected spinningmill. 
To compare the pretest andposttest level of knowledge on selected respiratory problems among workers in selected spinning mill.

To compare the pretest and posttest level of respiratory status among workers in selected spinningmill.

\section{Hypotheses :}

$>$ H1: posttest level of knowledge score is significantly higher than the mean pretest level of knowledge score among workers in the selected spinningmill.

$>\mathrm{H} 2$ : posttest level of symptom is significantly lower than flow $r$ pretest level of symptom of selected spinning mill.

H3: post test level of peak expiratory flow rate is significantly higher than the mean pretest level of peak expiratory flow rate among workers in the selected spinning mill.

ANALYSIS:

\section{METHODOLOGY}

Research design : One group pretest and posttestdesign.

Population : Spinning mill workers who were working in the selected spinning mill inDharapuram.

Sample : Workers who were working in the Kavin textile inDharapuram.

Sampling technique : Purposive sampling technique.

Sample size : 40 workers in the spinning mill.

Description of the tool :

Part -I Demographic variables .

Part_II Structured knowledge questionnaires regarding selected respiratory problems.

Part _III Observational check list to assess the level of respiratory symptoms.

Part _ IV Peak flow meter to assess the peak expiratory flowrate

Comparison of mean, standard deviation and paired ' $t$ ' value of Pretest and Posttest level of knowledge among workers in selectedspinningmill.

\begin{tabular}{|c|c|c|c|c|c|c|}
\hline S.No & Variable & Mean & $\begin{array}{c}\text { Standard } \\
\text { Deviation }\end{array}$ & $\begin{array}{c}\text { Mean } \\
\text { Difference }\end{array}$ & $\begin{array}{c}\text { Paired } \\
\text { 't' test } \\
\text { value }\end{array}$ & $\begin{array}{c}\text { Table } \\
\text { value }\end{array}$ \\
\hline 1 & Pretest & 9.3 & 7.03 & & & \\
2 & Post test & 22.6 & 2.49 & 13.3 & 22.8 & $2.02[\mathrm{~s}]$ \\
\hline
\end{tabular}

Pretest level of knowledge score was 9.3[Sㅁ+ 7.03] and Posttest mean score was 22.6[Sㅁ+2.49]

Comparison of mean, standard deviation and Paired ' $t$ ' value of Pretest and Posttest level of respiratory symptoms among workers in selectedspinningmills.

\begin{tabular}{|c|c|c|c|c|c|c|}
\hline S.No & Variable & Mean & $\begin{array}{c}\text { Standard } \\
\text { Deviation }\end{array}$ & $\begin{array}{c}\text { Mean } \\
\text { Difference }\end{array}$ & $\begin{array}{c}\text { Paired } \\
\text { 't test } \\
\text { value }\end{array}$ & $\begin{array}{c}\text { Table } \\
\text { value }\end{array}$ \\
\hline 1 & Pretest & 8.05 & 6.19 & & & \\
2 & Post test & 0.8 & 0.64 & 7.25 & 20.1 & $2.02[\mathrm{~s}]$ \\
\hline
\end{tabular}

Pretest level of respiratory symptoms score was $8.05(\mathrm{~S} \underline{\mathrm{D}}+6.19)$ and Posttest mean score was 0.8 (SD+0.64) 
The Posttest mean score (0.8) was lower than the Pretest mean score (8.05) The mean difference between Pretest and Posttest score was 7.25 . The paired ' $t$ ' value was $20.1 \%$ which was significant at $\mathrm{P}<0.05$ level.

ComparisonofmeanstandarddeviationandPaired't'valueofPretestandPosttestlevel of Peak expiratory flow rate among workers in selectedspinningmill. $n=40$

\begin{tabular}{|c|c|c|c|c|c|c|}
\hline S.No & Variable & Mean & $\begin{array}{c}\text { Standard } \\
\text { Deviation }\end{array}$ & $\begin{array}{c}\text { Mean } \\
\text { Difference }\end{array}$ & $\begin{array}{c}\text { Paired 't' test } \\
\text { value }\end{array}$ & $\begin{array}{c}\text { Table } \\
\text { value }\end{array}$ \\
\hline 1 & Pretest & 62.9 & 13.27 & & & \\
2 & Post test & 77.8 & 9.28 & 14.95 & 5.44 & $2.02[\mathrm{~s}]$ \\
\hline
\end{tabular}

Pretest level of Peak expiratory flow rate. was 62.9(Sㅁ⒔27) and Posttest mean was 77.8(Sㅁ⒐28). The Posttest mean score was higher than the Pretest t mean score (62.9).

The Posttest mean score (77.8) was higher than the Pretest mean score (62.9). The mean difference between Pretest and Posttest score was 14.95. The paired ' $\mathrm{t}$ ' value was 5.44 which was significant at $P$ $<0.05$ level.

Chi square values were calculated to find out the association between Posttest level of Respiratory symptoms among workers in the spinning mill with their selected demographic variable. The findings revealed that there was no significant association with demographic variables at $\mathrm{P}<0.05$ level of significance.

Chi square values were calculated to find out the association between Posttest level of Peak expiratory flow rate among workers in the Spinning mill, with their selected demographic variables. The findings revealed that there was no significant association with selected demographic variables at $\mathrm{P}<0.05$ level of significance.

\section{CONCLUSION:}

The results revealed that the teaching was highly effective in the improve the knowledge, reduce the level of respiratory symptomand improve the peak expiratory flow rate among workers in the spinning mill. Educational Interventions are necessary to improve the knowledge that will lead to improve the practice in the daily activities

\section{REFERENCE}

1. Denise F. Polit and Cheryl tatano beck ., Nursing Research generating and assessing evidence for nursing practice, $9^{\text {th }}$ edition Lippincott Williams and wilkins, London (2011) page no : 323-387.

2. Lewis et.al., Medical - Surgical Nursing, 7thedition Mosby publishers, Mossouri, (2011) , Page no : 498 -622.

3. Brunner et.al. , Text book of Medical Surgical Nursing, $10^{\text {th }}$ edition , Lippincott Williams, wilkins (2010), Page no : 532 $539,1251-1256$.

4. Gulani K.K., Text book of Community Health Nursing, Ist edition, Kumar publishers , NewDelhi, (2006), Page no : 103-146.

5. World Health Organization (WHO) , World health report ,2010), Report of director generalWHO. 